\title{
Innovations and Export Performance: Firm Level Evidence from China
}

\author{
Andrzej Cieślik, Yi Qu, Ting Qu
}

\begin{abstract}
A B S T R A C T
Objective: The goal of this article is to study the relationship between innovations and exporting of Chinese firms and identify which type of innovation contributes most to the probability of exporting.

Research Design \& Methods: We refer to the recent strand in the new trade theory literature that stresses the importance of firm productivity in entering export markets. We distinguish between product, process and managerial innovations that can increase productivity. The empirical investigation is based on the probit model and the firm-level data set covering two years: 2003 and 2012.
\end{abstract}

Findings: Our empirical results show that the probability of exporting is positively related to product and process innovations, firm size, foreign capital participation and foreign technology. Moreover, we find that in 2003 process innovations were more important for export performance than product innovations, while in 2012 it was the opposite.

Implications \& Recommendations: Firms should coordinate their strategic assets and resources for innovation in order to enhance their overall level of competitiveness. Governments should work on establishing stronger institutional environment necessary to provide firms with protection of intellectual property rights, an easier access to financing of innovation, a lower tax burden upon innovative firms, the higher quality of human resources to firms and more supportive policy packages.

Contribution \& Value Added: In contrast to previous that used only the R\&D spending as the measure of innovation in our study we also use innovation outcomes. In particular, we determine which innovation type is of greatest importance, having controlled for the set of other firm characteristics.

Article type: research article

Keywords: China; export activity; firm heterogeneity; innovations; probit model JEL codes: $\quad$ F14, P33

Received: 30 June 2018 Revised: 12 August 2018 Accepted: 16 August 2018

\section{Suggested citation:}

Cieślik, A., Qu, Y., \& Qu, T. (2018). Innovations and Export Performance: Firm Level Evidence from Chinese Firms. Entrepreneurial Business and Economics Review, 6(4), 27-47. https://doi.org/10.15678/EBER.2018.060402 


\section{INTRODUCTION}

Innovation is one of key issues related to the modernisation and development of the Chinese economy. However, empirical studies devoted to the role of innovation in firm export performance in China and other emerging economies still remain relatively scarce. One of the elements of innovation activity that is extensively studied in the context of firm export performance is research and development (R\&D) activity (e.g. Aw, Roberts, \& Xu, 2009; Hirsch \& Bijaoui, 1985; Spencer \& Brander, 1983; Zhao \& Li, 1997; Zhou \& Song, 2016). This activity is often described as the process of systematic creative work that combines both basic and applied research aimed at extending the company's knowledge resources and their practical applications. R\&D may also result in improved efficiency of the company (Aw et al., 2009).

However, innovation measures can include not only R\&D spending but also its effects. Innovations usually cover product and process innovations as well as the creation of intellectual property rights related to patents and trademarks (Qu \& Wei, 2017; Qu, Wei, Jiang, \& Zheng, 2017). Previous empirical evidence on the role of particular types of innovations in stimulating firm export performance focused mainly on firms located in advanced countries with high shares of innovative firms, such as Germany or the United Kingdom (e.g. Lachenmaier \& Wößmann, 2006; Roper \& Love, 2002; Wagner, 1996). However, these studies focused mainly on product and process innovations, while the empirical evidence for other forms of innovation is still scarce. Unfortunately, the number of studies that focus on the effects of innovation activities is still scarce, especially in the context of the Chinese economy.

Therefore, the main objective of this article is to study the relationship between innovations of Chinese firms and their export performance using various measures of innovation activities. In particular, we validate the general hypothesis concerning the positive relationship between innovations and exporting. Unlike previous studies that use only the $R \& D$ spending as the measure of innovation, in our study we also use innovation outcomes. Our specific hypotheses postulate positive relationships between firm export performance and three types of innovations: product, process and managerial innovations. In particular, we seek to determine which of the aforementioned innovation types is of greatest importance, having controlled for the set of other firm characteristics that were found important for exporting in previous empirical studies.

Our study is based on the firm-level data for Chinese firms collected by the World Bank for two years: 2003 and 2012. Our results can be useful in proposing policy recommendations that can apply to China as well as to other Newly Industrialised Countries (NICs), as firms from these countries still lag behind in terms of innovations compared to firms from more developed countries. Therefore, it is of particular importance to determine which of innovation types could contribute most to improving their export performance.

The remainder of this article is organised as follows. In the next section we survey the relevant literature on the relationship between various types of innovations and exporting. Then, we describe the analytical framework, discuss the research hypotheses, present 
definitions and sources of our explanatory variables and describe the empirical methodology. Finally, we discuss our estimation results. Concluding remarks, policy guidelines and directions for future research are provided in the last section.

\section{LITERATURE REVIEW}

There exists an extensive theoretical and empirical literature on determinants and effects of innovation in the context of advanced economies. In particular, the main hypothesis in this literature is that innovation can be regarded as a driver of productivity improvement at the firm-level that in turn could stimulate exports. The literature identified two main types of innovation that affect export performance: product and process innovations. Product innovation is the key factor for successful market entry in models of creative destruction and Schumpeterian growth, while process innovation reduces costs of production and strengthens the firm's market position. Both types of innovation are expected to raise firm's productivity and improve export performance.

In dynamic models with heterogeneous firms (Jovanovic, 1982; Hopenhayn, 1992; Melitz, 2003; Grossman, Helpman, \& Szeidl, 2006), investment in firm-specific assets that could be associated with product innovation leads to a selection of firms into export markets. In particular, less productive firms do not participate in export markets at all, while more productive ones supply consumers both at home and abroad. In this context, investment in firm-specific assets and a high total factor productivity are the key determinants of a firm's export propensity. ${ }^{1}$ Atkeson and Burstein (2007) and Constantini and Melitz (2008) developed dynamic models to formalise linkages between firm-level productivity and the choices of both to export and to invest in R\&D or adopt new technology. In their models, productivity distinguishes heterogeneous firms, and its evolution is affected by innovation decisions at the firm-level apart from a stochastic component.

There is also extensive empirical literature that points to a positive impact of innovations on exports. The majority of the existing studies rely on R\&D expenditures as a measure of innovation (Hirsch \& Bijaoui, 1985; Kumar \& Siddharthan, 1994; Braunerhjelm, 1996; Basile, 2001; Cieślik, Michałek, \& Michałek, 2012; 2014a, b, c; 2015). There is a limited number of studies that employ survey data with explicit information on actual innovation outcomes (Wagner, 1996; Wakelin, 1998; Bernard \& Jensen, 1999; Roper \& Love, 2002; Lachenmaier \& Wößmann, 2006; Cassiman, Golovko, \& Martínez-Ros, 2010; Van Beveren \& Vandenbussche 2010; Becker \& Egger 2013, Cieślik et al., 2016, Brodzicki, 2017, Cieślik \& Michałek, 2017; 2018).

Most studies on advanced economies found support for the positive relationship between innovations and exporting. In particular, it is found that firms that introduce either process or product innovation were more probable to export compared to the firms that do not innovate at all. Moreover, product innovations seem to be more important in affecting firm export performance than process innovations. In the remaining part of this section we summarise the literature devoted to studying the relationship between innovations and export performance in China.

\footnotetext{
1 The early industrial organisation literature stressed the role of marginal cost-reducing innovations in international oligopoly models (Spencer \& Brander, 1983). According to this literature, a higher investment in such innovations increases a firm's output sold in domestic and foreign markets.
} 
In one of the first empirical studies, Zhao and Li (1997) looked at the role of R\&D in affecting export propensity and export growth of Chinese manufacturing firms. Their results suggested that R\&D produced a positive and significant impact on both export propensity and growth. Subsequently, Liu and Shu (2003) investigated the determinants of export performance of Chinese industries. Their study revealed that FDI, labour costs and firm size were important determinants of export performance. In particular, FDI could bring about significant spillover effects which might positively affect the level of innovation capability of Chinese industries, and in turn boost their export performance.

In contrast, Guan and Ma (2003) looked at the role of innovation capabilities and firmlevel factors in affecting export performance of Chinese industrial firms. Overall, their study showed that harmonising and interaction of innovation assets can significantly promote their exports. More recently, Huang, Hu and Liu (2015) studied the relationship between innovation behaviour of firms and their export propensity. Their results suggested that firms would export only when their product or process innovations reach certain thresholds. Moreover, they found that product innovations had a stronger effect on exports than process innovations.

Zhou and Song (2016) looked at how trade participation affects the R\&D investment of Chinese manufacturing firms. Using firm-level data, their results reveal that channels such as geographical diversification of export markets can affect firm-level R\&D investment. Wei and An (2016) analysed relationships between innovation, institution and firm export performance. Their results revealed that innovation promoted export performance, however, institutions seemed to have a negative moderation effect on this relationship.

In this article we investigate whether different types of innovations improve the ability of Chinese firms, which are still less innovative compared to their counterparts located in the advanced economies, to compete in international markets. In contrast to previous studies we not only examine the relative importance for exporting product and process innovations, but also the role of managerial innovations and the ways innovations are introduced. Our study allows to formulate specific recommendations for the design of the economic policy in China and other NICs, especially for policies aimed at encouraging innovation in these countries.

\section{MATERIAL AND METHODS}

The latest strand in the New Trade Theory (NTT) literature that focuses on the role of firm heterogeneity in export performance argues that the level of firm productivity is critical for exporting. In particular, the Melitz (2003) model and its subsequent extensions point at the existence of a positive relationship between firm productivity and export performance. However, in his model productivity differences among firms are exogenously given and each firm has to pay fixed costs of entry into domestic and foreign markets. Following recent studies by Cieślik and Michałek (2017; 2018), in our article we refer to the modified Melitz (2003) model in which both productivity as well as the costs of export market entry can be endogenised as related to various types of innovations.

In our framework the dependent variable indicating the export status of firm $i$ is denoted by $Y_{i}^{*}$. However, instead of observing the volume of exports, we observe only a binary variable $Y_{i}$ indicating the sign of $Y_{i}^{*}$, i.e. whether the firm sells its output in the domestic market (local, regional or national) or it exports. Moreover, the variable 
$Y_{i}^{*}$ is assumed to follow $Y_{i}^{*}=\mathbf{X}_{\mathbf{i}} \boldsymbol{\Theta}+\varepsilon_{i}$, where the error term $\varepsilon_{i}$ is independent of $\mathbf{X}_{\mathbf{i}}$ which is a vector containing explanatory variables that affect exports with the first term equal to unity for all $i, \boldsymbol{\Theta}$ is the vector of parameters on these variables that needs to be estimated and $\varepsilon_{i}$ is assumed to be normally distributed with a zero mean.

Our dependent variable follows a binary distribution and takes the value 1 when the firm exports and 0 otherwise:

$$
Y_{i}=\left\{\begin{array}{l}
1 \text { if } Y_{i}^{*}>0 \\
0 \text { if } Y_{i}^{*}=0
\end{array}\right.
$$

We can obtain the distribution of $Y_{i}$ given $\mathbf{X}_{\mathbf{i}}$. Hence, the probability that a firm exports can be written as:

$$
P\left(Y_{i}=1 \mid \mathbf{X}_{\mathbf{i}}\right)=\Phi\left(\mathbf{X}_{\mathbf{i}} \Theta\right)
$$

where:

$\Phi()$ - denotes thestandard normal cumulative distribution function (cdf).

To be able to successfully employ the probit model, it is important to know how to interpret the vector of estimated parameters on the explanatory variables $\Theta$. Consider a specific explanatory variable $x_{i j}$, which is an element of vector $\mathbf{X}_{\mathbf{i}}$. The partial effect of $x_{i j}$ on the probability of exporting can be written as:

$$
\frac{\partial P\left(Y_{i}=1 \mid \mathbf{X}_{\mathbf{i}}\right)}{\partial x_{i j}}=\frac{\partial p\left(\mathbf{X}_{\mathbf{i}}\right)}{\partial x_{i j}}
$$

When multiplied by $\Delta x_{i j}$ equation (3) gives the approximate change in $P\left(Y_{i}=1 \mid \mathbf{X}_{\mathbf{i}}\right)$ when $x_{i j}$ increases by $\Delta x_{i j}$, holding all other variables constant.

The data sources used for this article are two World Bank Enterprise Surveys (WBES) on Chinese firms for the years 2003 and 2012, respectively. ${ }^{2}$ Those surveys were accomplished in collaboration with the Chinese National Bureau of Statistics. The WBES project is a World Bank project aiming to study the business environment and investment climate of selected countries at the firm-level. Firms in the survey are drawn from several industries and cities of the targeted country. The WBES 2003 dataset covers 2.400 firms from 18 major Chinese cities and 11 industries for three years with 7.200 observations altogether. In WBES 2003, questions are asked in relation to exports, innovation, foreign involvement, institutions, ownership structure, production, etc. ${ }^{3}$ The WBES 2012 dataset covers 2.700 firms from 25 major Chinese cities and 26 industries for the year 2011. In WBES 2012, questions are asked regarding exports, innovation, foreign involvement, ownership structure, production, inputs, outputs, etc. Despite only one year of observation, many questions in WBES 2012 are in relation to the situation of firms during the past three years, which are 2009-2011. ${ }^{4}$

Both 2003 and 2012 datasets are characterised by a high level of reliability and representativeness. Stratified sampling techniques were used to guarantee good representation of firms in selected industries and locations. Moreover, private contractors were hired to do face-to-face interviews with corporate managers and accountants of the major busi-

\footnotetext{
2 There is WBES on Chinese firms for 2005, however, it was not used in this study as WBES 2005 does not contain the variables that are needed to investigate our research questions.

${ }^{3}$ The data span is 2000-2002 for some variables such as exports, innovation, input, output, etc. However, for some variables, firms were interviewed only once in 2003, so the responses to such questions are only for the year 2002. ${ }^{4}$ For example, 'In the fiscal year 2011, what percentage of this establishment's total annual sales was accounted for by products or services that were introduced in the last three years?'.
} 
ness lines to assure that the collected data is of high quality. In China, only those with export licenses issued by the Ministry of Commerce of China can export. In order to apply for the license, a firm needs to provide required documents and show to the Ministry that its scope of business complies with regulations on exported commodities. With such a license, a firm can export directly or be an export agency and export on behalf of others indirectly. Therefore, a firm will be treated as an exporter as long as it has such a license, and this is consistent with the status of being an exporter in our dataset. For those engaged in exporting, they either export directly themselves (direct export) or sell their products to direct exporters or export agencies (indirect export).

In our study we selected a number of independent variables chosen from the survey, which reflect firm innovations and other firm characteristics. The variables description is presented in the Table 1.

Table 1. Independent variables used in the empirical study

\begin{tabular}{|c|c|}
\hline Independent variables & Definition \\
\hline $\begin{array}{l}\text { New product introduc- } \\
\text { tion (mainly used to } \\
\text { distinguish innovators } \\
\text { from non-innovators) }\end{array}$ & $\begin{array}{l}\text { Has this establishment introduced any new products or services? (Yes=1; } \\
\mathrm{No}=0 \text { ) }\end{array}$ \\
\hline \begin{tabular}{|l|} 
Innovation \\
engagement
\end{tabular} & $\begin{array}{l}\text { Has the firm engaged in identified types of innovation activities? (Yes=1; } \\
\text { No=0) }\end{array}$ \\
\hline R\&D & $\begin{array}{l}\text { Did this establishment spend on R\&D activities within the establishment? } \\
(Y e s=1 ; \mathrm{No}=0)\end{array}$ \\
\hline Patents & Does the firm have patent granted? $(\mathrm{Yes}=1 ; \mathrm{No}=0)$ \\
\hline $\begin{array}{l}\text { Product } \\
\text { innovation }\end{array}$ & $\begin{array}{l}\text { For WBES 2003: introduce new products (or services) in existing business } \\
\text { and entered new business line. } \\
\text { For WBES 2012: introduce new technology and equipment for product or } \\
\text { process improvements or not, introduce a new product or a new service } \\
\text { or not, and add new features to existing products or services or not. } \\
(\text { Yes=1; No=0) }\end{array}$ \\
\hline $\begin{array}{l}\text { Process } \\
\text { innovation }\end{array}$ & $\begin{array}{l}\text { For WBES 2003: New process improvements, new management tech- } \\
\text { niques and new quality controls in production. } \\
\text { For WBES 2012: introduce new quality control procedure in production or } \\
\text { operations or not, introduce new managerial/administrative processes or } \\
\text { not, provide technology training for staff or not, take measures to reduce } \\
\text { production cost or not, and take actions to improve production flexibility } \\
\text { or not. (Yes=1; No=0) }\end{array}$ \\
\hline $\begin{array}{l}\text { Managerial } \\
\text { innovation }\end{array}$ & $\begin{array}{l}\text { For WBES 2003: introduce new managerial/administrative processes or not. } \\
\text { For WBES 2012: introduce new managerial/administrative processes or } \\
\text { not and provides technology training for staff or not. } \\
(\text { Yes }=1 ; \mathrm{No}=0)\end{array}$ \\
\hline $\begin{array}{l}\text { Ways of introducing } \\
\text { product innovation }\end{array}$ & $\begin{array}{l}\text { Developed or adapted in house; Developed in cooperation with suppliers; } \\
\text { Developed in cooperation with client firms; Introduced your own version } \\
\text { of a product already supplied (by another firm); Implemented idea from } \\
\text { internal R\&D; Implemented idea from an external source, e.g. consult- } \\
\text { ants, universities and research institutions, etc. }\end{array}$ \\
\hline
\end{tabular}




\begin{tabular}{|l|l|}
\hline Independent variables & \multicolumn{1}{|c|}{ Definition } \\
\hline $\begin{array}{l}\text { Ways of introducing } \\
\text { process innovation }\end{array}$ & $\begin{array}{l}\text { Developed or adapted in house; Developed in cooperation with suppliers; } \\
\text { Developed in cooperation with client firms; Licensed technology or pro- } \\
\text { cess from another firm; Implemented idea from internal R\&D; Imple- } \\
\text { mented idea from an external source, e.g. consultants, universities and } \\
\text { research institutions. }\end{array}$ \\
\hline Firm size & The number of employees \\
\hline Firm age & The number of years since firm establishment \\
\hline Foreign technology & $\begin{array}{l}\text { Has the firm applied foreign technology? } \\
\text { (Yes=1; No=0) }\end{array}$ \\
\hline Foreign ownership & $\begin{array}{l}\text { Is the firm partly/wholly owned by foreign parties? } \\
\text { (Yes=1; No=0) }\end{array}$ \\
\hline
\end{tabular}

Source: own study.

The product innovation in this research refers to the creation of new products or the modifications of the functions of existing products. The process innovation refers to changes and improvements made on the ways of organising production including new techniques, new equipment and new organisational and managerial modes. Managerial innovation can therefore be regarded as a part of process innovation. Given the important role of managerial innovation in the firm's performance, in some of our regressions managerial innovation is picked out and its effect on the export of firms is evaluated.

The calculated values of correlations between explanatory variables for the years 2003 and 2012 are reported in Table 2 and 3, respectively. ${ }^{5}$

Table 2. Correlations between explanatory variables for WBES 2003

\begin{tabular}{|l|c|c|c|c|c|c|c|c|c|c|c|}
\hline \multicolumn{1}{|c|}{ Variable } & $\mathbf{( 1 )}$ & $\mathbf{( 2 )}$ & $\mathbf{( 3 )}$ & $\mathbf{( 4 )}$ & $\mathbf{( 5 )}$ & $\mathbf{( 6 )}$ & $\mathbf{( 7 )}$ & $\mathbf{( 8 )}$ & $\mathbf{( 9 )}$ & $\mathbf{( 1 0 )}$ & $\mathbf{( 1 1 )}$ \\
\hline (1) New Products & 1 & & & & & & & & & & \\
\hline (2) Patent & 0.091 & 1 & & & & & & & & & \\
\hline $\begin{array}{l}\text { (3) Innovation } \\
\text { Engagement }\end{array}$ & 0.195 & 0.190 & 1 & & & & & & & & \\
\hline (4) R\&D & 0.157 & 0.195 & 0.269 & 1 & & & & & & & \\
\hline (5) Firm Size & 0.176 & 0.150 & 0.219 & 0.288 & 1 & & & & & & \\
\hline (6) Firm Age & 0.059 & -0.029 & -0.062 & 0.100 & 0.375 & 1 & & & & & \\
\hline $\begin{array}{c}\text { (7) Foreign } \\
\text { Technology }\end{array}$ & 0.055 & 0.144 & 0.069 & 0.114 & 0.117 & -0.002 & 1 & & & & \\
\hline $\begin{array}{c}\text { (8) Foreign } \\
\text { ownership }\end{array}$ & 0.025 & -0.013 & 0.103 & 0.126 & 0.090 & -0.156 & 0.003 & 1 & & & \\
\hline $\begin{array}{c}\text { (9) Product } \\
\text { Innovation }\end{array}$ & 0.058 & 0.063 & 0.529 & -0.036 & 0.008 & 0.018 & 0.002 & -0.078 & 1 & & \\
\hline $\begin{array}{c}\text { (10) Process } \\
\text { Innovation }\end{array}$ & 0.185 & 0.128 & 0.756 & 0.164 & 0.174 & -0.003 & 0.098 & -0.000 & 0.204 & 1 & \\
\hline $\begin{array}{c}\text { (11) Managerial } \\
\text { Innovation }\end{array}$ & 0.118 & 0.071 & 0.718 & 0.093 & 0.126 & -0.007 & 0.076 & -0.009 & 0.154 & 0.811 & 1 \\
\hline
\end{tabular}

Source: own study.

\footnotetext{
${ }^{5}$ We report correlations among all the variables that were used in our study, but only some of them are associated with specific models we estimated.
} 
Table 3.1. Correlations between explanatory variables for WBES $2012^{6}$

\begin{tabular}{|l|c|c|c|c|c|c|c|c|c|c|}
\hline \multicolumn{1}{|c|}{ Variable } & $\mathbf{( 1 )}$ & $\mathbf{( 2 )}$ & $\mathbf{( 3 )}$ & $\mathbf{( 4 )}$ & $\mathbf{( 5 )}$ & $\mathbf{( 6 )}$ & $\mathbf{( 7 )}$ & $\mathbf{( 8 )}$ & $\mathbf{( 9 )}$ & $\mathbf{( 1 0 )}$ \\
\hline (1) New Product & 1 & & & & & & & & & \\
\hline (2) R\&D & 0.509 & 1 & & & & & & & & \\
\hline (3) Innovation Engagement & 0.304 & 0.261 & 1 & & & & & & & \\
\hline (4) Firm Size & 0.180 & 0.240 & 0.206 & 1 & & & & & & \\
\hline (5) Firm Age & 0.007 & 0.025 & 0.050 & 0.196 & 1 & & & & & \\
\hline (6) Foreign Technology & 0.283 & 0.205 & 0.120 & 0.232 & 0.016 & 1 & & & & \\
\hline (7) Foreign Ownership & 0.061 & 0.066 & 0.049 & 0.068 & -0.055 & 0.195 & 1 & & & \\
\hline (8) Product Innovation & 0.621 & 0.464 & 0.462 & 0.218 & 0.025 & 0.328 & 0.081 & 1 & & \\
\hline (9) Process Innovation & 0.407 & 0.373 & 0.606 & 0.269 & 0.061 & 0.245 & 0.098 & 0.687 & 1 & \\
\hline (10) Managerial Innovation & 0.349 & 0.309 & 0.509 & 0.282 & 0.055 & 0.246 & 0.110 & 0.601 & 0.869 & 1 \\
\hline
\end{tabular}

Source: own study.

Table 3.2. Correlations between explanatory variables of regressions in Tables 8 \& 9

\begin{tabular}{|c|c|c|c|c|c|c|c|c|c|c|}
\hline Variable & (1) & (2) & (3) & (4) & (5) & (6) & (7) & (8) & (9) & (10) \\
\hline $\begin{array}{l}\text { (1) Developed or adapted in } \\
\text { house }\end{array}$ & 1 & & & & & & & & & \\
\hline $\begin{array}{l}\text { (2) Developed in cooperation } \\
\text { with suppliers }\end{array}$ & 0.256 & 1 & & & & & & & & \\
\hline $\begin{array}{l}\text { (3) Developed in cooperation } \\
\text { with client firms }\end{array}$ & 0.245 & 0.518 & 1 & & & & & & & \\
\hline $\begin{array}{l}\text { (4) Introduced own version of } \\
\text { a product already supplied }\end{array}$ & 0.037 & 0.303 & 0.288 & 1 & & & & & & \\
\hline $\begin{array}{l}\text { (5) Implemented idea from in- } \\
\text { ternal R\&D }\end{array}$ & 0.585 & 0.129 & 0.189 & 0.114 & 1 & & & & & \\
\hline \begin{tabular}{|l|} 
(6) Implemented idea from an \\
external source
\end{tabular} & 0.272 & 0.384 & 0.279 & 0.282 & 0.302 & 1 & & & & \\
\hline (7) Firm age & 0.031 & -0.012 & -0.007 & -0.004 & 0.029 & 0.058 & 1 & & & \\
\hline (8) Firm size & \begin{tabular}{|l|l|}
0.134 \\
\end{tabular} & 0.065 & 0.052 & 0.024 & 0.130 & 0.151 & 0.222 & 1 & & \\
\hline (9) Foreign technology & 0.042 & 0.107 & 0.057 & 0.144 & 0.021 & 0.177 & 0.006 & 0.212 & 1 & \\
\hline (10) Foreign ownership & 0.015 & 0.053 & 0.080 & -0.002 & 0.025 & 0.097 & -0.052 & 0.051 & 0.190 & 1 \\
\hline
\end{tabular}

Source: own study.

Table 3.3. Correlations between explanatory variables of regressions in Tables 10 \& 11

\begin{tabular}{|l|c|c|c|c|c|c|c|c|c|c|}
\hline Variable & (1) & (2) & (3) & (4) & (5) & (6) & (7) & (8) & (9) & (10) \\
\hline $\begin{array}{c}\text { (1) Developed or adapted in } \\
\text { house }\end{array}$ & 1 & & & & & & & & & \\
\hline $\begin{array}{c}\text { (2) Developed in cooperation } \\
\text { with suppliers }\end{array}$ & 0.303 & 1 & & & & & & & & \\
\hline $\begin{array}{c}\text { (3) Developed in cooperation } \\
\text { with client firms }\end{array}$ & 0.244 & 0.451 & 1 & & & & & & & \\
\hline
\end{tabular}

\footnotetext{
${ }^{6}$ The WBES 2012 dataset does not have patent data as WBES 2003 does. Therefore, we cannot include patent data in our estimations. Due to the fact that too many variables will appear in one correlation table, the correlation test of 'the ways of introducing product and process innovations' is reported in sub-tables separately.
} 


\begin{tabular}{|l|c|c|c|c|c|c|c|c|c|c|}
\hline \multicolumn{1}{|c|}{ Variable } & $\mathbf{( 1 )}$ & $\mathbf{( 2 )}$ & $\mathbf{( 3 )}$ & $\mathbf{( 4 )}$ & $\mathbf{( 5 )}$ & $\mathbf{( 6 )}$ & $\mathbf{( 7 )}$ & $\mathbf{( 8 )}$ & $\mathbf{( 9 )}$ & $\mathbf{( 1 0 )}$ \\
\hline $\begin{array}{c}\text { (4) Introduced own version of a } \\
\text { product already supplied }\end{array}$ & 0.009 & 0.325 & 0.317 & 1 & & & & & & \\
\hline $\begin{array}{c}\text { (5) Implemented idea from in- } \\
\text { ternal R\&D }\end{array}$ & 0.508 & 0.148 & 0.251 & 0.127 & 1 & & & & & \\
\hline $\begin{array}{l}\text { (6) Implemented idea from an } \\
\text { external source }\end{array}$ & 0.189 & 0.310 & 0.260 & 0.355 & 0.286 & 1 & & & & \\
\hline (7) Firm age & 0.025 & -0.025 & -0.002 & 0.034 & 0.032 & 0.048 & 1 & & & \\
\hline (8) Firm size & 0.147 & 0.048 & 0.071 & 0.101 & 0.163 & 0.124 & 0.221 & 1 & & \\
\hline (9) Foreign technology & 0.013 & 0.067 & 0.036 & 0.249 & 0.064 & 0.214 & 0.006 & 0.215 & 1 & \\
\hline (10) Foreign ownership & 0.005 & 0.043 & 0.079 & 0.041 & 0.027 & 0.080 & -0.055 & 0.051 & 0.195 & 1 \\
\hline
\end{tabular}

Source: own study.

\section{RESULTS AND DISCUSSION}

In this section we report estimation results for each year of our sample: 2003 and 2012, respectively. Estimation results for the year 2003 are reported in Table 4 where exporting refers to the combination of direct and indirect exports of products and services.

Table 4. Innovation and Propensity to Export in 2003

\begin{tabular}{|l|c|c|c|c|}
\hline \multicolumn{1}{|c|}{ Variable } & $(\mathbf{1})$ & $\mathbf{( 2 )}$ & $\mathbf{( 3 )}$ & (4) \\
\hline New Products & 0.042 & & & \\
\hline Patents & $(0.076)$ & & & \\
\hline & & $0.216^{* * *}$ & & \\
\hline Innovation Engagement & & $(0.059)$ & & \\
\hline & & & $0.152^{* * *}$ & \\
\hline R\&D & & & $(0.048)$ & \\
\hline & & & & $0.353^{* * *}$ \\
\hline Firm Size & & & & $(0.044)$ \\
\hline & $0.307^{* * *}$ & $0.319^{* * *}$ & $0.32^{* * *}$ & $0.302^{* * *}$ \\
\hline Firm Age & $(0.022)$ & $(0.015)$ & $(0.015)$ & $(0.015)$ \\
\hline & $-0.015^{* * *}$ & $-0.017^{* * *}$ & $-0.017^{* * *}$ & $-0.017^{* * *}$ \\
\hline Foreign Technology & $(0.002)$ & $(0.002)$ & $(0.002)$ & $(0.002)$ \\
\hline & $-0.189^{* * *}$ & -0.140 & -0.106 & -0.182 \\
\hline Foreign Ownership & $(0.135)$ & $(0.116)$ & $(0.114)$ & $(0.114)$ \\
\hline & $0.951^{* * *}$ & $0.881^{* * *}$ & $0.861^{* * *}$ & $0.825^{* * *}$ \\
\hline Number of observations & $(0.082)$ & $(0.064)$ & $(0.064)$ & $(0.065)$ \\
\hline$R^{2}$ & 2961 & 6889 & 7005 & 7005 \\
\hline
\end{tabular}

Notes: 1. Innovation activity is measured by new product introduction (Yes/No); Patent granted (Yes/No); innovation engagement (Yes/No); R\&D (Yes/No); 2. Control variables include: firm size; firm age; foreign technology; foreign ownership; 3 . Robust standard errors are reported in parentheses. ${ }^{* * *},{ }^{* *}$ and ${ }^{*}$ indicate that the coefficient is significantly different from zero at the $1 \%, 5 \%$ and $10 \%$ levels, respectively; 4 . In order to save on space the estimates of constant terms are not reported.

Source: own study.

In column (1) of Table 4 we report results where our innovation measure is a dummy variable indicating whether the firm introduced any new products, having controlled for 
its characteristics such as size, age, the use of foreign technology and foreign ownership. It turns out that this measure is not statistically significant at all, while all control variables are statistically significant already at the $1 \%$ level.

In column (2) we show results where our innovation measure is a dummy variable indicating whether the firm was granted a patent. This measure is significant at the $1 \%$ level and displays an expected positive sign. In column (3) we report results where our innovation measure is a dummy variable indicating whether the firm is engaged in innovation. The estimated coefficient on this variable displays an expected positive sign and is significant at the $1 \%$ level.

Finally, for the sake of comparison with the earlier studies based on innovation inputs, such as Cieślik et al. (2014a, b, c; 2015; 2016), in column (4) we present results where our innovation measure is a dummy variable indicating whether the firm undertook R\&D. This variable is significant at the $1 \%$ level and displays a positive sign, which confirms the importance of R\&D for exporting, documented in previous studies for other countries, also for China. In particular, this result is in line with the results of the early study by Zhao and Li (1997) who demonstrated that R\&D produced a positive and significant effect on exports.

Estimation results from Table 4 indicate that patents, innovation engagement and R\&D are positively and significantly related to firm's propensity to export in 2003. Moreover, new product introduction was found to generate no effect on firm's propensity to export. In addition, our estimation results revealed that firm characteristics, such as firm size, firm age and foreign ownership were important determinants of firm export performance.

In Table 5 we report estimation results for the year 2003 in which we distinguish between specific types of innovation: product innovation, process innovation and managerial innovation.

Table 5. Product, Process and Managerial Innovation and Propensity to Export in 2003

\begin{tabular}{|l|c|c|c|c|}
\hline \multicolumn{1}{|c|}{ Variable } & $(\mathbf{1})$ & $\mathbf{( 2 )}$ & $\mathbf{( 3 )}$ & (4) \\
\hline Product Innovation & -0.034 & 0.036 & & \\
\hline & $(0.029)$ & $(0.025)$ & & \\
\hline Process Innovation & $0.098^{* * *}$ & & $0.087^{* * *}$ & \\
\hline Managerial Innovation & $(0.020)$ & & $(0.017)$ & \\
\hline & & & & $0.167^{* * *}$ \\
\hline Firm Size & & & & $(0.042)$ \\
\hline & $0.312^{* * *}$ & $0.325^{* * *}$ & $0.311^{* * *}$ & $0.317^{* * *}$ \\
\hline Firm Age & $(0.015)$ & $(0.015)$ & $(0.015)$ & $(0.015)$ \\
\hline & $-0.017^{* * *}$ & $-0.018^{* * *}$ & $-0.017^{* * *}$ & $-0.017^{* * *}$ \\
\hline Foreign Technology & $(0.002)$ & $(0.002)$ & $(0.002)$ & $(0.002)$ \\
\hline & -0.134 & -0.102 & -0.137 & $-0.119^{* * *}$ \\
\hline Foreign Ownership & $(0.115)$ & $(0.116)$ & $(0.115)$ & $(0.115)$ \\
\hline & $0.862^{* * *}$ & $0.870^{* * *}$ & $0.859^{* * * *}$ & $0.87^{* * *}$ \\
\hline Number of observations & $(0.064)$ & $(0.064)$ & $(0.064)$ & $(0.064)$ \\
\hline$R^{2}$ & 7005 & 7005 & 7005 & 6951 \\
\hline Notes: 1 in model(1), both produt and & 0.159 & 0.155 & 0.159 & 0.157 \\
\hline
\end{tabular}

Notes: 1. In model (1), both product and process innovation measures are included, while in models (2) and (3), only one of these measures is included; 2 . Innovation activity is measured by product, process and managerial innovations. Following the existing literature, the sum of responses to the questions: 'Introduced new products (or services) in existing business' and 'Entered new business line' is treated as a product innovation, while the 
sum of response to questions: 'New process improvements', 'New management techniques' and 'New quality controls in production' is treated as a process innovation. The response to the question: 'introduce new managerial/administrative processes or not' is treated as a managerial innovation.

Source: own study.

In column (1) of Table 5 we report results where we included dummies for product and process innovations, having controlled for other firm characteristics. It turns out that only the process innovation variable is significant at the $1 \%$ level and displays the expected positive sign. In columns (2) and (3) we report estimation results obtained separately for product and process innovations. These results confirm our findings from column (1) as the product innovation variable is not significant and the process innovation variable remains significant at the $1 \%$ level. Finally, in column (4) we report results obtained for managerial innovations. Our measure of managerial innovations is significant at the $1 \%$ level and displays the expected positive sign.

The results from Table 5 indicate that both process innovation and managerial innovation produced positive and significant effects on a firm's propensity to export in 2003. At the same time product innovation was found to generate no significant effects on a firm's propensity to export. This means that only process innovation (i.e. new process improvements, new management techniques and new quality controls in production) and managerial innovation (i.e. introduce new managerial/administrative processes or not) are significant contributing factors to exporting of firms rather than product innovation (introduced new products/services in existing business and entered new business line). The empirical results obtained for the control variables were similar to those reported in Table 4.

The results on the relationship between various measures of innovation and propensity to export for the year 2012 are reported in Table 6. The particular columns of Table 6 are the counterparts of the columns in Table 4.

In columns (4)-(6) we enrich our analysis by reporting estimation results for indirect exports. Columns (4)-(6) of Table 6 are direct counterparts of columns (1)-(3). It turns out that all innovation measures are significant at the $1 \%$ level and display positive signs. The results from Table 6 indicate that new production introduction, innovation engagement and R\&D have positive and significant effects on firm's propensity to export both directly and indirectly. Moreover, these results also reveal that firm size and foreign ownership affect positively firm's propensity to both direct and indirect export, while the use of foreign technology significantly affects only firm's propensity to export directly. Firms that use foreign technology are more likely to engage in direct exporting. Finally, these results suggest that larger firms and/or firms with foreign ownership (partly/wholly owned by foreign parties) are more likely to engage in both direct and indirect exporting. Comparing the results based on WBES 2003 dataset reported in Table 4 with the results based on WBES 2012 dataset reported in Table 6 it can be noted that major difference is the significance of new product introduction in the more recent set of estimates. This may suggest that Chinese firms are moving away from process innovation toward product innovation, which makes them more similar to the firms from advanced economies where product innovation plays a more important role than process innovation. 
Table 6. Innovation and Propensity to Export (Direct and Indirect) in 2012

\begin{tabular}{|c|c|c|c|c|c|c|}
\hline \multirow{2}{*}{ Variable } & \multicolumn{3}{|c|}{ Direct exports } & \multicolumn{3}{|c|}{ Indirect exports } \\
\hline & (1) & (2) & (3) & (4) & (5) & (6) \\
\hline \multirow[t]{2}{*}{ New Product } & $0.130^{*}$ & & & $0.356^{* * *}$ & & \\
\hline & $(0.078)$ & & & $(0.079)$ & & \\
\hline \multirow[t]{2}{*}{ Innovation Engagement } & & $0.125^{* * *}$ & & & $0.397^{* * *}$ & \\
\hline & & $(0.130)$ & & & $(0.144)$ & \\
\hline \multirow[t]{2}{*}{$R \& D$} & & & $0.287^{* * *}$ & & & $0.322^{* * *}$ \\
\hline & & & $(0.076)$ & & & $(0.078)$ \\
\hline \multirow[t]{2}{*}{ Firm Size } & $0.285^{* * *}$ & $0.288^{* * *}$ & $0.274^{* * *}$ & $0.067^{* *}$ & $0.070^{* *}$ & $0.055^{*}$ \\
\hline & $(0.030)$ & $(0.030)$ & $(0.030)$ & $(0.029)$ & $(0.029)$ & $(0.029)$ \\
\hline \multirow[t]{2}{*}{ Firm Age } & -0.002 & -0.003 & -0.001 & -0.001 & -0.001 & -0.004 \\
\hline & (0.004) & $(0.004)$ & $(0.005)$ & $(0.004)$ & $(0.005)$ & $(0.005)$ \\
\hline \multirow[t]{2}{*}{ Foreign Technology } & $0.261^{* * *}$ & $0.294^{* * *}$ & $0.239^{* * *}$ & -0.009 & 0.075 & 0.047 \\
\hline & $(0.087)$ & $(0.084)$ & $(0.085)$ & $(0.093)$ & $(0.091)$ & $(0.091)$ \\
\hline \multirow[t]{2}{*}{ Foreign Ownership } & $0.817^{* * *}$ & $0.820^{* * *}$ & $0.826^{* * *}$ & $0.251^{*}$ & $0.255^{*}$ & $0.259^{*}$ \\
\hline & $(0.126)$ & $(0.126)$ & $(0.126)$ & $(0.137)$ & $(0.135)$ & $(0.137)$ \\
\hline Number of observations & 1630 & 1635 & 1625 & 1630 & 1634 & 1625 \\
\hline$R^{2}$ & 0.115 & 0.116 & 0.123 & 0.025 & 0.017 & 0.023 \\
\hline
\end{tabular}

Notes: 1. Innovation activity is measured by new product introduction (Yes/No); innovation engagement (Yes/No among the sum of 8 innovation categories); R\&D (Yes/No); 2. Control variables include: firm size (the log of the number of full-time employees); firm age; foreign technology or not (whether the firm has foreign technologies); foreign ownership or not (whether the firm is partly/wholly owned by foreign parties).

Source: own study.

In Table 7 we report our estimation results for 2012 in which we distinguish between specific types of innovation: product innovation, process innovation and managerial innovation for direct and indirect exporting, respectively. The particular columns of Table 7 are the counterparts of the columns in Table 5.

In columns (1)-(2) of Table 7 we report results for direct and indirect exports, respectively, where we include the dummies for both product and process innovations, having controlled for other firm characteristics. It turns out, however, that in contrast to the results reported in column (1) of Table 5 only the measure of product innovation activities is significant at the $1 \%$ level and displays the expected positive sign, while the measure of process innovations is not significant in the case of direct and indirect exports.

In columns (3)-(4) and (5)-(6) we report results for direct and indirect exports, respectively, obtained separately for product and process innovations. These estimation results confirm our findings from columns (1) and (2) for the product innovation which remains significant at the $1 \%$ level in the case of both direct and indirect exports. However, our estimation results show that the product innovation variable remains not significant only in the case of direct exports, while in the case of indirect exports it is significant at the $1 \%$ level and displays the expected positive sign.

Finally, in columns (7)-(8) we report results obtained for managerial innovations for direct and indirect exports, respectively. Our measure of managerial innovations is significant only at the $5 \%$ level and displays the expected positive sign only in the case of indirect exports while in the case of direct exports it is not significant. 
Table 7. Product, Process and Managerial Innovation and Propensity to Export (Direct and Indirect) in $\mathbf{2 0 1 2}$

\begin{tabular}{|l|c|c|c|c|c|c|c|c|}
\hline \multirow{4}{*}{ Variable } & Direct & Indirect & Direct & Indirect & Direct & Indirect & Direct & Indirect \\
\cline { 2 - 9 } & $\mathbf{( 1 )}$ & $\mathbf{( 2 )}$ & $\mathbf{( 3 )}$ & $\mathbf{( 4 )}$ & $\mathbf{( 5 )}$ & $\mathbf{( 6 )}$ & $\mathbf{( 7 )}$ & $\mathbf{( 8 )}$ \\
\hline Product Innovation & $0.129^{* * *}$ & $0.147^{* * *}$ & $0.103^{* * *}$ & $0.148^{* * *}$ & & & & \\
\hline & $(0.042)$ & $(\mathbf{0})$ & $(\mathbf{0})$ & $(\mathbf{0 .}$ & & & & \\
\hline Process Innovation & -0.028 & 0.001 & & & & & & \\
\hline & $(0.030)$ & $(0.031)$ & & & $(0.023)$ & $(0.022)$ & & \\
\hline Managerial Innovation & & & & & & & 0.058 & $0.114^{* *}$ \\
\hline & & & & & & & $(0.049)$ & $(0.05)$ \\
\hline Firm Size & $0.286^{* * *}$ & $0.062^{* *}$ & $0.282^{* * *}$ & $0.062^{* *}$ & $0.285^{* * *}$ & $0.064^{* *}$ & $0.285^{* * *}$ & $0.066^{* *}$ \\
\hline & $(0.031)$ & $(0.029)$ & $(0.030)$ & $(0.029)$ & $(0.030)$ & $(0.029)$ & $(0.030)$ & $(0.029)$ \\
\hline Firm Age & -0.002 & -0.001 & -0.002 & -0.001 & -0.003 & -0.001 & -0.003 & -0.001 \\
\hline & $(0.004)$ & $(0.005)$ & $(0.004)$ & $(0.005)$ & $(0.004)$ & $(0.005)$ & $(0.004)$ & $(0.005)$ \\
\hline Foreign Technology & $0.221^{* *}$ & -0.026 & $0.221^{* *}$ & -0.026 & $0.276^{* * *}$ & 0.044 & $0.281^{* * *}$ & 0.057 \\
\hline & $(0.089)$ & $(0.093)$ & $(0.089)$ & $(0.093)$ & $(0.085)$ & $(0.092)$ & $(0.085)$ & $(0.092)$ \\
\hline Foreign Ownership & $0.831^{* * *}$ & $0.267^{*}$ & $0.822^{* * *}$ & $0.267^{*}$ & $0.813^{* * *}$ & $0.247^{*}$ & $0.813^{* * *}$ & $0.245^{*}$ \\
\hline & $(0.127)$ & $(0.137)$ & $(0.127)$ & $(0.137)$ & $(0.126)$ & $(0.135)$ & $(0.126)$ & $(0.135)$ \\
\hline Number of observations & 1635 & 1635 & 1635 & 1635 & 1635 & 1635 & 1635 & 1635 \\
\hline$R^{2}$ & 0.122 & 0.026 & 0.121 & 0.026 & 0.116 & 0.017 & 0.116 & 0.015 \\
\hline
\end{tabular}

Notes: 1. In models (1) and (2), both product and process innovations are included, while in models (3)-(6), only one of them is included; 2 . Innovation is measured by product, process and managerial innovations. Following the existing literature, the sum of responses to the questions: 'introduce new technology and equipment(s) for product or process improvements or not', 'introduce new product or new service or not' and 'add new features to existing products or services or not' is treated as product innovation; while, the sum of response to questions: 'introduce new quality control procedure in production or operations or not', 'introduce new managerial/administrative processes or not', 'provide technology training for staff or not', 'take measures to reduce production cost or not' and 'take actions to improve production flexibility or not' is treated as process innovation. The sum of responses to the questions: 'introduce new managerial/administrative processes or not' and 'provide technology training for staff or not' is treated as managerial innovation.

Source: own estimations performed in STATA 14.

The results from Table 7 for the year 2012 show that in contrast to the results from Table 5 for the year 2003 product innovations had positive and statistically significant effects on firm's propensity to direct and indirect export. It was also found that process and managerial innovations generate significant effects only in the case of indirect exports. This means that product innovation (i.e. introducing new technology and equipment(s) for product or process improvements, introducing new product or new service and adding new features to existing products or services) is a more important factor in direct exports of Chinese firms in 2012 than process innovation (i.e. introducing new quality control procedures in production or operations, introducing new managerial and administrative processes, providing technology training for staff, taking measures to reduce production cost and taking actions to improve production flexibility) and managerial innovation (i.e. introducing new managerial/administrative processes and providing technology training for staff)..$^{7}$ Firms that engaged in

\footnotetext{
${ }^{7}$ There are overlaps between the two as managerial innovation is a part of process innovation, but we look at their impact separately.
} 
product innovation were more likely to engage in both direct and indirect exporting while those that engaged in process and managerial innovations only in indirect exporting. Hence, comparing the results based on WBES 2003 dataset with the results based on WBES 2012 dataset it can be stated that product innovation has become a more significant contributor to firm's propensity to export than process innovation and managerial innovation.

In addition, the results obtained for 2012 confirm that firm size and foreign ownership have positive and significant impacts on a firm's propensity to both direct and indirect export, while foreign technology matters only in the case of direct exporting. The results suggest that a larger firm or a firm with foreign ownership (partly/wholly owned by foreign parties) is more likely to engage in both direct and indirect exporting. At the same time, a firm with foreign technology is more likely to engage in direct exporting.

Data for 2012 allows us also to study in a detailed way how product and process innovations are introduced and how these ways affect the probability of direct and indirect exports. In particular, we distinguished between innovations that were developed or adapted in house, developed in cooperation with suppliers, developed in cooperation with client firms, an own version of a product already supplied, an implemented idea from internal R\&D, an implemented idea from an external source.

In Table 8 we report results obtained for the specification in which we studied the relationship between the probability of direct exporting and various ways in which product innovations were introduced.

Table 8. Ways of Introducing Product Innovations on Direct Exporting in 2012

\begin{tabular}{|l|c|c|c|c|c|c|}
\hline \multicolumn{1}{|c|}{ Variable } & $\mathbf{( 1 )}$ & $\mathbf{( 2 )}$ & $\mathbf{( 3 )}$ & $\mathbf{( 4 )}$ & $\mathbf{( 5 )}$ & $\mathbf{( 6 )}$ \\
\hline Developed or adapted in house & -0.108 & & & & & \\
\hline & $(0.087)$ & & & & & \\
\hline Developed in cooperation with suppliers & & $0.163^{*}$ & & & & \\
\hline & & $(0.085)$ & & & & \\
\hline Developed in cooperation with client firms & & & 0.12 & & & \\
\hline & & & $(0.08)$ & & & \\
\hline Introduced own version of a product \\
already supplied
\end{tabular}

Source: own estimations performed in STATA 14. 
The results from Table 8 reveal that developing a product innovation in cooperation with suppliers and implementing the idea from an external source are the only two ways of introducing product innovation that contributed significantly to the direct exporting of Chinese firms. Moreover, the statistical significance of the former way was only $10 \%$, while of the latter it was $1 \%$. These results suggest that cooperation and communication with external parties in terms of innovation constitute important ways of promoting direct exports of Chinese firms.

In Table 9 we report results obtained for the specification in which we studied the empirical relationship between the probability of indirect direct exporting and various ways in which product innovations were introduced.

Table 9. Ways of Introducing Product Innovations on Indirect Exporting in 2012

\begin{tabular}{|l|c|c|c|c|c|c|}
\hline \multicolumn{1}{|c|}{ Variable } & $\mathbf{( 1 )}$ & $\mathbf{( 2 )}$ & $\mathbf{( 3 )}$ & $\mathbf{( 4 )}$ & $\mathbf{( 5 )}$ & $\mathbf{( 6 )}$ \\
\hline Developed or adapted in house & -0.016 & & & & & \\
\hline & $(0.088)$ & & & & & \\
\hline Developed in cooperation with suppliers & & 0.098 & & & & \\
\hline Developed in cooperation with client firms & & & $0.222^{* * *}$ & & & \\
\hline & & & $(0.081)$ & & & \\
\hline Introduced own version of a product & & & & $0.204^{* *}$ & & \\
\hline already supplied & & & & & & \\
\hline & & & & $(0.082)$ & & \\
\hline Implemented idea from internal R\&D & & & & & 0.019 & \\
\hline & & & & & $(0.084)$ & \\
\hline Implemented idea from an external source & & & & & & $0.383^{* * *}$ \\
\hline & & & & & & $(0.084)$ \\
\hline Firm Size & $0.057^{*}$ & $0.052^{*}$ & $0.051^{*}$ & $0.061^{* *}$ & $0.055^{*}$ & 0.035 \\
\hline & $(0.03)$ & $(0.031)$ & $(0.031)$ & $(0.031)$ & $(0.031)$ & $(0.031)$ \\
\hline Firm Age & 0.001 & 0.001 & 0.002 & 0.001 & 0.001 & 0.0001 \\
\hline & $(0.004)$ & $(0.004)$ & $(0.004)$ & $(0.004)$ & $(0.004)$ & $(0.005)$ \\
\hline Foreign Technology & 0.09 & 0.099 & 0.107 & 0.085 & 0.104 & 0.032 \\
\hline & $(0.093)$ & $(0.095)$ & $(0.094)$ & $(0.097)$ & $(0.093)$ & $(0.094)$ \\
\hline Foreign Ownership & $0.247^{*}$ & $0.235^{*}$ & 0.206 & $0.266^{*}$ & $0.251^{*}$ & 0.219 \\
\hline & $(0.139)$ & $(0.140)$ & $(0.14)$ & $(0.141)$ & $(0.14)$ & $(0.141)$ \\
\hline Number of observations & 1441 & 1427 & 1427 & 1424 & 1436 & 1433 \\
\hline$R^{2}$ & 0.007 & 0.009 & 0.014 & 0.014 & 0.008 & 0.023 \\
\hline
\end{tabular}

Source: own estimations performed in STATA 14.

In contrast to the earlier set of results for direct exporting reported in Table 8, the estimation results from Table 9 reveal that cooperation with client firms, the introduction of own version of a product already supplied and the implementation of ideas from external sources are three main ways of introducing product innovation that contribute significantly to the indirect exports of Chinese firms. The major difference between these two sets of results lies in the role of cooperation with client firms which points at the existence of the forward linkage compared to the role of cooperation with the supplier firms, pointing at the existence of the backward linkage in the case of direct exporting. Another important difference is the significant role of own version of already supplied products in the case of indirect 
exporting. The main similarities include the statistically significant role of the implementation of an idea from an external source for both direct and indirect exporting and the lack of statistical significance of all other ways of introducing product innovations.

In Table 10 we report estimation results obtained for the specification in which we studied the empirical relationship between the probability of direct exporting and various ways in which process innovations were introduced.

Table 10. Ways of Introducing Process Innovations on Direct Exporting in 2012

\begin{tabular}{|c|c|c|c|c|c|c|}
\hline Variable & (1) & (2) & (3) & (4) & (5) & (6) \\
\hline \multirow[t]{2}{*}{ Developed or adapted in house } & -0.069 & & & & & \\
\hline & $(0.088)$ & & & & & \\
\hline \multirow[t]{2}{*}{ Developed in cooperation with suppliers } & & -0.025 & & & & \\
\hline & & $(0.083)$ & & & & \\
\hline \multirow[t]{2}{*}{ Developed in cooperation with client firms } & & & $0.164^{* *}$ & & & \\
\hline & & & $(0.081)$ & & & \\
\hline \multirow{2}{*}{$\begin{array}{l}\text { Introduced own version of a product } \\
\text { already supplied }\end{array}$} & & & & 0.043 & & \\
\hline & & & & $(0.085)$ & & \\
\hline \multirow[t]{2}{*}{ Implemented idea from internal R\&D } & & & & & -0.053 & \\
\hline & & & & & $(0.086)$ & \\
\hline \multirow[t]{2}{*}{ Implemented idea from an external source } & & & & & & $0.185^{* *}$ \\
\hline & & & & & & $(0.083)$ \\
\hline \multirow[t]{2}{*}{ Firm Size } & $0.281^{* * *}$ & $0.281^{* * *}$ & $0.277^{* * *}$ & $0.281^{* * *}$ & $0.283^{* * *}$ & $0.277^{* * *}$ \\
\hline & $(0.031)$ & $(0.031)$ & $(0.031)$ & $(0.031)$ & $(0.031)$ & $(0.031)$ \\
\hline \multirow[t]{2}{*}{ Firm Age } & -0.003 & -0.004 & -0.003 & -0.004 & -0.003 & -0.003 \\
\hline & $(0.004)$ & $(0.004)$ & $(0.005)$ & $(0.005)$ & $(0.004)$ & $(0.005)$ \\
\hline \multirow[t]{2}{*}{ Foreign Technology } & $0.311^{* * *}$ & $0.333^{* * *}$ & $0.322^{* * *}$ & $0.309^{* * *}$ & $0.318^{* * *}$ & $0.288^{* * *}$ \\
\hline & \begin{tabular}{|l|}
$(0.086)$ \\
\end{tabular} & \begin{tabular}{|l|}
$(0.087)$ \\
\end{tabular} & $(0.087)$ & \begin{tabular}{|l|}
$(0.09)$ \\
\end{tabular} & $(0.087)$ & $(0.089)$ \\
\hline \multirow[t]{2}{*}{ Foreign Ownership } & $0.838^{* * *}$ & $0.829^{* * *}$ & $0.815^{* * *}$ & $0.834^{* * *}$ & $0.844^{* * *}$ & $0.846^{* * *}$ \\
\hline & $(0.131)$ & $(0.131)$ & $(0.132)$ & $(0.131)$ & $(0.131)$ & $(0.131)$ \\
\hline Number of observations & 1438 & 1426 & 1428 & 1426 & 1436 & 1433 \\
\hline$R^{2}$ & 0.109 & 0.112 & 0.114 & 0.111 & 0.111 & 0.115 \\
\hline
\end{tabular}

Source: own estimations performed in STATA 14.

The estimation results reported in Table 10 show that cooperation with client firms and the implementation of ideas from external sources are the only two ways of introducing process innovation that contribute significantly to the direct exporting of firms. The major difference between these results and the results obtained for product innovations reported in Table 8 is the significant role of cooperation with client in contrast to the role of cooperation with the supplier firms that was significant in the case of product innovation. At the same time, these results are very similar to the results reported in Table 9 for product innovation in the case of indirect exporting.

Finally, in Table 11 we report estimation results obtained for the specification in which we studied the empirical relationship between the probability of indirect direct exporting and various ways how process innovations were introduced. 
Table 11. Ways of Introducing Process Innovations on Indirect Exporting in 2012

\begin{tabular}{|l|c|c|c|c|c|c|}
\hline \multicolumn{1}{|c|}{ Variable } & $\mathbf{( 1 )}$ & $\mathbf{( 2 )}$ & $\mathbf{( 3 )}$ & $\mathbf{( 4 )}$ & $\mathbf{( 5 )}$ & $\mathbf{( 6 )}$ \\
\hline Developed or adapted in house & -0.006 & & & & & \\
\hline & $(0.089)$ & & & & & \\
\hline Developed in cooperation with suppliers & & 0.059 & & & & \\
\hline & & $(0.084)$ & & & & \\
\hline Developed in cooperation with client firms & & & $0.255^{* * *}$ & & & \\
\hline & & & $(0.082)$ & & & \\
\hline $\begin{array}{l}\text { Introduced own version of a product } \\
\text { already supplied }\end{array}$ & & & & 0.020 & & \\
\hline & & & & $(0.087)$ & & \\
\hline Implemented idea from internal R\&D & & & & & 0.101 & \\
\hline & & & & & $(0.088)$ & \\
\hline Implemented idea from an external source & & & & & & $0.354^{* * *}$ \\
\hline & & & & & & $(0.083)$ \\
\hline Firm Size & & & & & & \\
\hline & $0.058^{*}$ & $0.060^{*}$ & $0.053^{*}$ & $0.059^{*}$ & $0.054^{*}$ & 0.047 \\
\hline Firm Age & $(0.031)$ & $(0.031)$ & $(0.031)$ & $(0.031)$ & $(0.031)$ & $(0.031)$ \\
\hline & 0.002 & 0.001 & 0.002 & 0.001 & 0.001 & 0.001 \\
\hline Foreign Technology & $(0.004)$ & $(0.004)$ & $(0.004)$ & $(0.004)$ & $(0.004)$ & $(0.004)$ \\
\hline & 0.102 & 0.119 & 0.118 & 0.100 & 0.099 & 0.022 \\
\hline Foreign Ownership & $(0.093)$ & $(0.094)$ & $(0.094)$ & $(0.097)$ & $(0.093)$ & $(0.095)$ \\
\hline & $0.246^{*}$ & $0.236^{*}$ & 0.211 & $0.243^{*}$ & $0.246^{*}$ & $0.239^{*}$ \\
\hline Number of observations & $(0.14)$ & $(0.14)$ & $(0.141)$ & $(0.14)$ & $(0.14)$ & $(0.141)$ \\
\hline$R^{2}$ & 1438 & 1426 & 1428 & 1426 & 1436 & 1433 \\
\hline Source: own stimations perfor & 0.008 & 0.009 & 0.016 & 0.008 & 0.009 & 0.022 \\
\hline
\end{tabular}

Source: own estimations performed in STATA 14.

The results reported in Table 11 are very similar to the results reported previously in Table 10. In particular, these results show that the development of cooperation with client firms and the implementation of ideas from external sources are two main ways of introducing process innovations that contribute significantly to the indirect exports of Chinese firms. Therefore, in contrast to the results obtained for product innovations we do not find any differences with respect to the ways process innovations are introduced between direct and indirect exports.

\section{CONCLUSIONS}

In this article we studied the relationship between innovations and export performance of Chinese firms. Our analytical framework referred to the recent strand in the NTT literature based on the Melitz (2003) model. We treated innovations as a key element that can increase the level of productivity and focused on product and process innovations and intellectual property creation. We also analysed the role of foreign ownership and foreign technology. Our results indicated that the probability of exporting was positively related to product and process innovations, firm size, foreign capital participation and foreign technology. Moreover, our results suggest that there has been a shift from process to product innovation overtime. At the same time it is worth noting that product innovation is related either to external 
sources, such as the links with clients and suppliers of intermediate inputs, or implemented ideas from external sources. Our study has reached different results and findings from other studies as it not only focuses on one of the largest emerging country-China and Chinese firms but also use unique dataset and distinguishes between different types of innovation which have yet been investigated in Chinese context, and the results and implications from this study are important for both policy makers and corporate managers.

Future efforts should be targeted at encouraging in-house innovations. Both firms and governments of various levels should work together to improve firms' capability of making in-house innovations. First, firms should coordinate their strategic assets and resources for innovation such as R\&D personnel, capital, technologies and information and invest in developing R\&D capability as innovation can not only promote exports but also enhance their overall level of competitiveness. Second, governments should work on establishing a stronger formal institutional environment which is able to provide firms with strong protection of intellectual property rights, an easier access to financing of innovation, a lower tax burden upon innovative firms, the higher quality of human resources to firms and more supportive policy packages to encourage in-house and independent innovations. Hence, future research relating to this topic should focus on the role of in-house innovations and their effects. Furthermore, for government policy makers the building of formal institutional constructs such as effective and efficient national innovation system is very important, as it can promote innovation of firms and thereby their export performance. In this regard, building external networks between firms, universities, R\&D institutes, governments and financial resource providers is quite necessary and fundamental for firms in strengthening their innovation capability and hence export performance. As for corporate managers, they should actively build and participate in networking activities with other parties in the national innovation system and cooperate with other players in the game of innovation, such as other firms, universities, R\&D institutes, governments and financial resource providers in order to enhance their promoter of export, in this case, their innovation capability.

\section{REFERENCES}

Atkeson, A., \& Burstein A. (2007). Innovation, firm dynamics, and international trade. (NBER working paper, no. 13326). https://doi.org/10.1086/653690

Aw, B.Y., Roberts, M.J., \& Xu, D.Y. (2009). R\&D investment, exporting, and productivity dynamics. (NBER working paper, no. 14670). https://doi.org/10.1086/65369010.1257/aer.101.4.1312

Basile, R. (2001). Export behavior of Italian manufacturing firms over the nineties: the role of innovation. Research Policy, 30, 1185-1201. https://doi.org/10.1016/S0048-7333(00)00141-4

Becker, S.O., \& Egger, P.H. (2013). Endogenous product versus process innovation and a firm's propensity to export. Empirical Economics, 44, 329-354. https://doi.org/10.1007/s00181-009-0322-6

Bernard, A., \& Jensen, J.B. (1999). Exceptional export performance: cause, effect, or both?. Journal of International Economics, 47, 1-25. https://doi.org/10.1016/S0022-1996(98)00027-0

Braunerhjelm, P. (1996). The relation between firm specific intangibles and exports. Economic Letters, 53, 213-219. https://doi.org/10.1016/S0165-1765(96)00898-1

Brodzicki, T. (2017). Internationalisation and Innovation Intensities of Polish Manufacturing Firms: A Close Nexus?. Entrepreneurial Business and Economics Review, 5(1), 91-109. https://doi.org/10.15678/EBER.2017.050106 
Caldera, A. (2010). Innovation and exporting: evidence from Spanish manufacturing firms. Review of World Economy, 146, 657-689. https://doi.org/10.1007/s10290-010-0065-7

Cassiman, B., Golovko, E., \& Martínez-Ros, E. (2010). Innovation, exports and productivity. International Journal of Industrial Organization, 28, 372-376. https://doi.org/10.1016/j.ijindorg.2010.03.005

Cieślik, A., Michałek, J.J., \& Michałek, A. (2012). Export activity in Visegrad-4 countries: Firm level investigation. Ekonomia, Rynek, Gospodarka, Społeczeństwo, 30, 7-22.

Cieślik, A., Michałek, J.J., \& Michałek, A. (2014a). The Influence of Firm Characteristics and Export Performance in Central and Eastern Europe: Comparisons of Visegrad, Baltic and Caucasus states. Entrepreneurial Business and Economics Review, 2(1), 4-18. https://doi.org/10.15678/EBER.2014.020102

Cieślik, A., Michałek, J.J., \& Michałek, A. (2014b). European integration and firm's export performance in the new EU member countries. Poznań University of Economics Review, 14(4), 38-53.

Cieślik, A., Michałek, J.J., \& Michałek, T. (2014c). Firm characteristics and export performance in postcommunist countries. In N. Daszkiewicz \& K. Wach (Eds.), Firm-Level Internationalisation and Its Business Environment, Knowledge-based and Entrepreneurial Approach (pp. 34-45). Gdańsk: Gdańsk University of Technology Publishing House. https://doi.org/10.13140/2.1.3832.9282

Cieślik, A., Michałek, J.J., Michałek, A., \& Mycielski, J. (2015). Determinants of export performance: Comparison of Central European and Baltic firms. Finance a Uver, 65(3), 211-229.

Cieślik, A., Michałek, J.J., \& Szczygielski, K. (2016). Innovations and Export Performance: Firm-level Evidence from Poland. Entrepreneurial Business and Economics Review, 4(4), 11-28. https://doi.org/10.15678/EBER.2016.040402

Cieślik, A., \& Michałek, J.J. (2017). Innovation Forms and Firm Export Performance: Empirical Evidence from ECA Countries. Entrepreneurial Business and Economics Review, 5(2), 85-99. https://doi.org/10.15678/EBER.2017.050205

Cieślik, A., \& Michałek, J.J. (2018). Firm-level determinants of direct and indirect exports: empirical evidence for C.E.E. and M.E.N.A. countries. Economic Research-Ekonomska Istraživanja, 31(1), 982-996. https://doi.org/10.1080/1331677X.2018.1436452

Constantini, J.A., \& Melitz, M.J. (2008). The dynamics of firm-level adjustment to trade liberalization. In E. Helpman, D. Marin \& T. Verdier (Eds.), The organization of firms in a global economy (pp. 107 - 141). Cambridge, MA: Harvard University Press.

De Loecker, J. (2007). Do exports generate higher productivity? Evidence from Slovenia. Journal of International Economics, 73(1), 69-98. https://doi.org/10.1016/j.jinteco.2007.03.003

Grossman, G.M., Helpman, E., \& Szeidl, A. (2006). Optimal integration strategies for the multinational firm. Journal of International Economics, 70, 216-238. https://doi.org/10.1016/j.jinteco.2005.07.011

Guan, J., \& Ma, N. (2003). Innovative capabilities and export performance of Chinese firms. Technovation, 23(9), 737-747. https://doi.org/10.1016/S0166-4972(02)00013-5

Hirsch, S., \& Bijaoui, I. (1985). R\&D Intensity and export performance: a micro view. Weltwirtschaftliches Archiv, 121, 138-151. https://doi.org/10.1007/BF02705822

Hopenhayn, H.A. (1992). Entry, exit, and firm dynamics in long run equilibrium. Econometrica, 60, 1127-1150. https://doi.org/10.2307/2951541

Huang, X., Hu, X., \& Liu, Y. (2015). Product innovation, process innovation and export propensity of Chinese firms. Economics (Chinese Journal), 4, 22-30.

Jovanovic, B. (1982). Selection and the evolution of industry. Econometrica, 50, 649-670. https:/doi.org/10.2307/1912606 
Kumar, N., \& Siddharthan, N.S. (1994). Technology, firm size and export behavior in developing countries: the case of Indian enterprise. Journal of Development Studies, 32, 288-309. https://doi.org/10.1080/00220389408422362

Lachenmaier, S., \& Wößmann, L.W. (2006). Does innovation cause exports? Evidence from exogenous innovation impulses and obstacles using German micro data. Oxford Economic Papers, 58, 317-350. https://doi.org/10.1093/oep/gpi043

Liu, X., \& Shu, C., (2003). Determinants of export performance of Chinese industries. Economics of Planning, 36, 45-67. https://doi.org/10.1023/B:ECOP.0000005728.05260.5d

Melitz, M.J. (2003). The impact of trade on intra-industry reallocations and aggregate industry productivity. Econometrica, 71, 1695-1725. https://doi.org/10.1111/1468-0262.00467

Roper, S., \& Love, J.H. (2002). Innovation and export performance: evidence from the UK and German manufacturing plants. Research Policy, 31, 1087-1102. https://doi.org/10.1016/S00487333(01)00175-5

Spencer, B.J., \& Brander, J.A. (1983). International R\&D rivalry and industrial strategy. Review of Economic Studies, 50(4), 707-722. https://doi.org/10.2307/2297771

Van Beveren, I., \& Vandenbussche, H. (2010). Product and process innovation and firms' decision to export. Journal of Economic Policy Reform, 13(1), 3-24. https://doi.org/10.1080/17487870903546267

Wagner, J. (1996). Export performance, human capital, and product innovation in Germany: a micro view. Jahrbuch für Wirtschaftswissenschaften, 47, 40-45.

Wakelin, K. (1997). Trade and Innovation. Theory and Evidence. Cheltenham: Edward Elgar.

Wakelin, K. (1998). Innovation and export behaviour at the firm level. Research Policy, 26(7-8), 82941. https://doi.org/10.1016/S0048-7333(97)00051-6

Wei, W., \& An, X. (2016). Innovation, institutions and export performance. Research on Financial and Economic Issues (Chinese Journal), 3, 45-60.

Qu, Y., \& Wei, Y. (2017). The Role of Domestic Institutions and FDI on Innovation-Evidence from Chinese Firms. Asian Economic Papers, 16(2), 55-76. https://doi.org/10.1162/ASEP_a_00519

$\mathrm{Qu}, \mathrm{Y}$., Qu, T., \& Wu, Y. (2017). The role of regional formal institutions and foreign direct investment in innovation in Chinese enterprises. Asia Pacific Business Review, 23(1), 27-43. https://doi.org/10.1080/13602381.2015.1094293

Qu, Y., Wei, Y., Jiang, T., \& Zheng, N. (2017). Linking R\&D strategy, national innovation system and FDI to firm performance. Journal of Chinese Economic and Business Studies, 15(1), 41-58. https://doi.org/10.1080/14765284.2016.1242310

Zhao, H., \& Li, H. (1997). R\&D and export: An empirical analysis of Chinese manufacturing firms. Journal of High Technology Management Research, 8(1), 89-105. https://doi.org/10.1016/S1047-8310(97)90015-8

Zhou, Y., \& Song, L. (2016). International trade and R\&D investment: Evidence from Chinese manufacturing firms. China and World Economy, 24(1), 63-84. https://doi.org/10.1111/cwe.12144 


\section{Authors}

The contribution share of authors is equal and amounted to $33 \%$ each of them.

\section{Andrzej Cieślik}

Professor in the area of International Economics in the Faculty of Economic Sciences of the University of Warsaw (Poland). PhD in Economics from the University of Warsaw (Poland).

Correspondence to: Prof. Andrzej Cieślik, PhD, University of Warsaw, Faculty of Economic Sciences, ul. Długa 44/50, 00-241 Warsaw, Poland, e-mail: cieslik@wne.uw.edu.pl

\section{Yi Qu}

Senior Lecturer in Business and Management in Surrey International Institute of the Dongbei University of Finance and Economics (China). PhD in Management from the University of York (UK). Correspondence to: Dr Yi Qu, 10-2, Uuit 2, Building 43, Zhi Xin Yuan (Guo Ji Xin Cheng), Wu Yi Road, Dalian City, Liaoning Province, China, e-mail: quyijerry@dufe.edu.cn

\section{Ting Qu}

Researcher in Management and Regional Economy in the Institute of Regional Economy and System Engineering of Hunan Academy of Social Sciences (China). PhD in Management (Korea).

Correspondence to: Dr. Ting Qu, No. 37, Liuhecun Lane, Deya Road, Kaifu District, Changsha City, Hunan Province, China, e-mail: quting323@163.com

\section{Copyright and License}

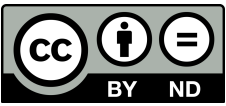

This article is published under the terms of the Creative Commons

Attribution - NoDerivs (CC BY-ND 4.0) License http://creativecommons.org/licenses/by-nd/4.0/

\section{Published by the Centre for Strategic and International Entrepreneurship - Krakow, Poland}


